\title{
VULTURES AND CANDLES AS METAPHORS OF LEADERSHIP FAILURES IN EMEKA NWABUEZE'S A PARLIAMENT OF VULTURES AND UCHE-CHINEMERE NWAOZUZU'S THE CANDLES
}

Emeka Aniago

Department of Theatre and Film Studies, University of Nigeria, Nsukka, Nigeria emekaaniago@gmail.com / ORCID iD: 0000-0003-3194-1463

\section{Norbert Oyibo Eze}

Department of Theatre and Film Studies, University of Nigeria, Nsukka, Nigeria

\author{
Stella Okoye-Ugwu \\ Department of English and Literary Studies, University of Nigeria, Nsukka, \\ Nigeria
}

\author{
Divine Sheriff Joe \\ Department of Theatre and Film Studies, Imo State University, Owerri, Nigeria
}

\begin{abstract}
Poor leadership has unarguably been recognized as a major national question around which many socioeconomic and political problems revolve in Nigeria. It has led to decadence and a squandermania mentality which breeds all sort of vices, mass poverty, absent and decaying infrastructure, kidnapping, agitations, banditry, and all kinds of insurgency. Playwrights, like other social scientists, have continued to interrogate this ugly phenomenon, which make socioeconomic and political development a will-o'-the-wisp in the country. This paper attempts to examine Emeka Nwabueze's A Parliament of Vultures and Uche-Chinemere Nwaozuzu's The Candles, especially as they deploy the vulture and the candle, respectively, as metaphors to elucidate the question of leadership failure in the unstable and politically explosive minefield that is Nigeria. The study adopts Clifford Geertz's thick description approach to interpretation as its methodology. The researchers discovered that self-aggrandizement, incompetence, "firebrigade approach," poor institutions, lack of meritocracy, blackmail, and violence were the social realities that encumber the flowering of good governance in the country.
\end{abstract}




\section{Keywords}

corruption, democracy, military, politics socioeconomic, squandermania, thick description

\section{About the Authors}

Emeka Aniago is a senior lecturer in the Department of Theatre and Film Studies at the University of Nigeria, Nsukka where he received his MA in Drama and Theatre Arts before obtaining his $\mathrm{PhD}$ in Theatre and Film Studies from the University of Wales, UK. He has contributed book chapters, co-edited books, and published articles in reputable journals across the globe. He is President of the Africology Research Network.

Norbert Oyibo Eze is a senior lecturer in the Department of Theatre and Film Studies at the University of Nigeria, Nsukka where he received his $\mathrm{PhD}$ in Dramatic Studies. He is a published playwright with several book chapters and articles published in highly acclaimed international journals.

Stella Okoye-Ugwu is a senior lecturer in the Department of English and Literary Studies at the University of Nigeria, Nsukka where she earned her PhD. Her papers have appeared in several international and national journals.

Divine Sheriff Joe is currently completing his $\mathrm{PhD}$ in Theatre Studies at Imo State University, Owerri after receiving his MA from the University of Nigeria, Nsukka. His research papers are published in both national and international journals. 


\section{INTRODUCTION}

There are a good number of scholarly works extensively touching on various trajectories of poor leadership realities and challenges facing Nigeria. However, no visible study has interpretively analyzed the nuances and polemics of the vulture and candle metaphors as projected in Emeka Nwabueze's A Parliament of Vultures and Uche-Chinemere Nwaozuzu's The Candles. Hence, this paper attempts to interpretively analyze and evaluate the question of poor leadership in the two plays, especially as they deploy the vulture and the candle as aesthetic devices of communicating the retrogressive tendencies and despicable use of political power by Nigerian leaders. The plays are deliberately chosen to show that Nigeria's problems have remained a major concern in spite of claims about progress by the political elite. The texts will be scrutinized interpretively in order to lucidly explain how the leaders in their various guises and poses can be likened to vultures and how candles typify these retrogressive tendencies in line with culturespecific attributions in Nigeria. To add analytical rigor as a means of enhancing plausibility of analysis, we applied the theory of social construction of reality and the interpretive theory.

In A Parliament of Vultures and The Candles, the playwrights separately indicate that the quest by Nigerians to be governed by progressive leaders has continued to grow in leaps and bounds, yet the painful cases of monumental, less-than-admirable leadership outcomes has remained a plague to Nigeria. In A Parliament of Vultures, Nwabueze portrays a political culture whereby the politicians take the masses for granted and engage in callous, disdainful, reckless, and indelicate conduct. The play clearly portrays a society where the political scene is crowded by unruly and unpatriotic characters, such as Chief Habamero (the Speaker of Parliament), Rev. Jossy, Mr. Brown, and Madam Omeaku, who are depicted as the "vultures in Parliament." A Parliament of Vultures mostly revolves around Madam Omeaku, who through collaboration with a sleazy political gang rose from an illiterate, lowclass, street-side food-and-liquor vendor to a profligate parliamentarian. Nwabueze satirically depicts how Madam Omeaku, the play's epitome of the vulture metaphor, and other nefarious political bedfellows dubiously became parliamentarians. The play also highlights the entrenchment of the generational progression of sociopolitical corruption in Nigeria, whereby the aspirants' requisite experience and credentials are not what propel their chances of winning elections, but rather their victories at the polls are achieved through rigging, vote buying, dastard elimination of political opponents, and "gutter politics" (Aniago 72).

Furthermore, the play depicts how Madam Omeaku misbehaves, both in the parliament and at home, and her attempts to introduce her daughter to her

unethical political inclination. In parliament, Madam Omeaku disregards due 
process, exhibits recklessness, profanity, impunity, and crass mediocrity. At home, she henpecks her husband, telling him that despite his more than thirty years of toil in the civil service, he has nothing tangible to show for it while she can embark on choice holidays overseas and purchase expensive houses and cars, just within a year of being a Nigerian parliamentarian. However, the play indicates that in the parliament are a few well-meaning politicians such as Dr. Parkers and Mr. Otobo, who firmly oppose the subsisting looting and maladministration but are consistently hounded because they rebuff attempts to get them to compromise. The play's story gets to its climax when the youths, who are not willing to tolerate the unsavoury actions of the "vultures in parliament" anymore, start an uprising coordinated by some university student activists to flush out the nefarious parliamentarians.

Just as A Parliament of Vultures captures the heart-rending debauchery, incompetence, and humongous looting in a supposedly democratic civilian regime, The Candles is a dark, socio-political satire that explores various layers of socioeconomic regression, leadership incompetence, and proclivity for numinous miracles as a means of solving regular socio-political realities by a totalitarian military regime. The text, in a dense innuendo, projects the abysmal performance of the military regimes in Nigeria. Its story commences in a room where a nighttime secret gathering of fortune tellers captioned the "Annual National Herbalists Convention" is held. The names of the invited fortune tellers are Amadioha, Ogun, and Usman, representing the Igbo, Yoruba, and Hausa, respectively which are the three major ethnic groups in Nigeria.

The playwright at the beginning of the play rapidly introduces what we view as salient thematic foci of the play, which include the metaphors for light/illumination and darkness/regression. This introduction occurs when Mr. Koko, the Federal Minister of Information, is interrupted in his formal welcome address to the fortune tellers by an abrupt power outage. This is after he had managed to note that it is only the very top brass of the military regime, namely the military president, the "Service Chiefs," the secretary to the military government, and of course himself are aware of their mission. Thus, it is for the purpose of secrecy and exclusivity that it is holding at a very remote part of the Federal Capital Territory. In response to the sudden power outage, frantic efforts to switch over to a standby power generator prove futile because the power generator cannot start. The generator's inability to start is blamed on the menace of adulterated petrol. One of the fortune tellers suggests that since the nearest city is about three hours journey, both going and return, that it is expedient that they use candles to provide illumination and get started with the duty at hand because they have barely three hours to complete their task. Eventually, candles were procured to illuminate the room. However, the attempts through numinous means to unmask the individuals who attempt 
to topple the military government yielded unsatisfactory results. The rumoured revolution eventually occurs.

\section{LITERATURE REVIEW}

In his assessment of the political climate in Nigeria from 1999 to 2017, Emeka Aniago observes that "one of the major topical concerns that have taken the centre stage in scholarly as well as pedestrian discourses in Nigeria in recent time is the apparent intractable web of Nigeria's socio-political woes" (25). Furthermore, he notes that "the nuances and shades of opinions on the topic are in many ways interesting and at the same time disturbing" because "a common essence in relation to the topic is polemics of corruption and leadership failure" (Aniago 25). Adding their voices to this discourse, it is apparent that the two plays A Parliament of Vultures and The Candles in many ways portray realities and pains of leadership failure in Nigeria, and how it has become an existential circumstance with troubling ramifications for the country's polity, politics, and socioeconomic development.

In a bid to foreground the purview of this discussion, we shall review relevant critical thematic expressions and concepts. According to Iain McLean and Alistair McMillan, politics as a general concept represents "the practice of the art or science of directing and administering states or other political units" (422). Furthermore, they observe that "the definition of politics is highly, perhaps essentially, contested" (422). This is because among other things "there is considerable disagreement on which aspects of social life ought to be considered political" (422). The scholars add that "the traditional definition of politics, 'the art and science of government,' offers no constraint on its application, since there has never been a consensus on which activities count as government," which leads them to ask: "is government confined to the state? Does it not also take place in church, guild, estate, and family?" (McLean and McMillan 423). Thus, the position of McLean and McMillan suggests that politics pervades every aspect of life were human-social units exist. Illuminating this further, Paul Chilton and Christina Schaffner explain that politics represents "a struggle for power, between those who seek to assert and maintain their power and those who seek to resist it" (5). They also contend that politics subsumes nuances and modalities of "cooperation, as to the practices and institutions a society has in resolving clashes of interest over money, power, liberty and the like" (5). The contribution of Chilton and Schaffner points out what actually takes place in politics, which is primarily the seeking, appropriation, and application of power in one way or the other. 
Talking about appropriation and application of power, scholars like Chinua Achebe, Obaro Ikime, and C. B. Okolo, among others, have attributed the multiple socioeconomic and political problems facing Nigeria, and which has contributed to make genuine development in the country difficult to poor political leadership. Achebe posits that "the trouble with Nigeria is simply and squarely a failure of leadership" (1). For him Nigeria has been very unfortunate with its leadership due to the leaders' inability to live above parochial interests. Elaborating on this, Okolo notes that:

The right concept of power or power as service to the people, for the protection and promotion of their good is little known and rarely practised in Nigeria. Rather, it is often wielded for self and equally against others. Positions of power and authority invariably turn out to be sources of gain, financial security and political leaders see their time in office as a grand opportunity for over-reaching themselves at the expense of the common man. (86)

It is common knowledge that societal values are incarnated by the leaders and no nation has ever grown beyond the values inaugurated by her leaders. The culture of selfishness and squandermania mentality_introduced and nurtured by successive postcolonial Nigerian leaders both military and democratic-has been at the root of a myriad of fear-inducing socioeconomic and political challenges that have continued to make development very difficult. Due to this deplorable situation, the Nigerian masses experience affliction of hardship on a daily basis in a land endowed with enormous natural resources. In 2019, Nigeria was dubbed the "poverty capital" of the world by the World Poverty Clock (Iheonu and Urama 2).

On democracy, Michael Bratton and Richard Houessou reveal that Africans' taste for rule of law as prerequisite for good governance is increasing, hence "Africans express growing attachment to democracy according to citizen attitude surveys conducted by the Afro-barometer in 34 countries" (1). Furthermore, they observe that "seven out of ten Africans prefer democracy to other regimes" and that the proportion of deeply committed democrats "has risen steadily over the past decade" (1). Regardless of this growing positive disposition to democracy in Africa and Nigeria in particular, a litany of reports and scholarly contributions indicate that the masses mostly contend that the dividends of democracy are far below their expectation. In a report authored by Nic Cheeseman titled "Why Democracy and Authoritarianism Are Both on the Rise in Africa," produced for the Bertlesmann Transformation Index depicting democratic trends between 2015 and 2018, there is a presentation of two very important conclusions about the state of democracy in Africa in the period under review. According to the report: 
First, the continent experienced an overall deterioration in the quality of almost all indicators of political and economic governance. The fall is not massive, though, and so it makes more sense to speak of democratic difficulties than democratic collapse. However, the decline is real. Its impact has been to move the continent further away from political stability, democratisation, and economic sustainability. Second, there is not one 'Africa.' Instead, it's essential to look beyond regional averages because they mask a remarkably divided continent. Today there is almost the same number of defective democracies (15) as there are hard line autocracies (16), among the continent's 54 states. (Cheeseman 1)

Towards the end of the last century, Nigeria returned to democratic rule in 1999 after years of dictatorial military administrations. Consequently, the democratic experience in Nigeria can still be classified as nascent and fledgling with tendencies of growing with time. However, the crux of the matter is that despite the strides made in the post-military era commencing from 1999, the question that still reechoes is if Nigeria is practicing democracy as it should be. This question leads us to point at the nuance of social context, which helps us to appreciate and theorize that though democracy has universally common features, it exhibits local specific realities as a result of several variables. In portraying the social context of democracy in Nigeria, a number of authors point to the realities of socio-political institutions and structures. Thus, on the state of democracy in Nigeria, Dare Arowolo and Tolu Lawal opine that:

Present democratization process in Nigeria suffers from several problems. First, it is being carried out within inefficient and non-viable rules. Second, the process itself allows for manipulation of existing rules. Third, the counteracting agencies charged with policing and enforcement of the laws and those who work in these agencies are not properly constrained by the laws, and INEC (Independent National Electoral Commission) itself is not divested of this 'pathology' and as such cannot be relied upon to play a role expected of an umpire since it is the party in power that appoints its officials and funds its operation. (179)

Placing the above comment in perspective, Kabir Adejumo observes that " 20 years after uninterrupted democratic governance, the celebration is vanity due to a high level of corruption, poverty, decaying infrastructure, unemployment, insecurity and other irregularities" (1). Similarly, Adekola Adeagbo and Olumide Omodunbi state that "since good leadership is the foundation of every progressive democracy, the defective system practiced in Nigeria cannot guarantee the true dividends of democracy" (120). Victor Ojakorotu and Fidelis Allen posit that the problems of most developing democracies mainly revolve around the inability of the existing socio-political institutions, structures, and frameworks to propel and sustain democratic principles such as rule of law, separation of power, and due process. They note that the process and practice of democracy are flawed in 
many ways. On the issues raised by Ojakorotu and Allen which revolves around the negative effects of weak and dysfunctional political framework, institutions, and structures, we observe that many scholars believe that democracy can only thrive in Nigeria when there are strong, independent, and optimally functional political institutions.

In discussing the vulture and candle metaphors in the focus plays, we apply the interpretive discussion approach. As April Vannini explains, "the expression interpretive theory, refers to a relatively large umbrella category that includes analytical perspectives and theories spanning the fields of communication, sociology, anthropology, education, cultural studies, political science, history, and the humanities" (557). She describes interpretive theories as "ontological and epistemological tools used in research concerned with understanding how individuals and groups create meaning in their everyday practices, communication, and lived experiences" (557). A vivid implication of Vannini's explanation is that from one place to the other, lived experiences are expected not to be exactly the same, hence Iain Black observes that "beyond subjectivity, the interpretive paradigm is one that thrives upon subtlety; it is one where hidden and important meaning is buried within superficially inconsequential inflections of voice, body language or situational details" (320).

To Geoff Walsham, "interpretive methods of research start from the position that our knowledge of reality, including the domain of human action, is a social construction by human actors" (320). He observes that "theories concerning reality are ways of making sense of the world, and shared meanings are a form of intersubjectivity rather than objectivity" (Walsham 320). In addition, Vannini notes that, "interpretive theories sometimes referred to as interpretivism or philosophical interpretivism are orientations to social reality based on the goal of understanding" hence, interpretive theories help analysts and critics to articulate perspectives to human diversity based on rationalisation (557). Hence, interpretivism denotes an approach to studying social life with the assumption "that the meaning of human action is inherent in that action" (Schwandt 134). Illuminating further, Vannini suggests that those of interpretivist school of thought are:

Scholars who are interested in the ways communities, cultures, or individuals, create meaning from their own actions, rituals, interactions, and experiences; scholars who wish to interpret local meanings by locating them into a broader historical, geographical, political, linguistic, ideological, economic, and cultural milieu; researchers who look at the meanings of texts and the codes and rules on which they rely to convey meaning; and theory and philosophy-oriented scholars who explore ideas of meaning and interpretation in and of themselves. (557) 
In relation to Vannini's contribution, Emeka Aniago explains that for a researcher "to fully comprehend the quintessential characteristics of interpretivism as well as to better appreciate its uniqueness and usefulness, it is useful to begin by looking at its philosophical origins and then juxtaposing interpretivist theories with trajectories found in narrative paradigm" (269). In an attempt to foreground thick description as a trajectory of interpretive approach, Clifford Geertz describes data researchers collect in culture-based research in the following words: "what we call our data are really our own constructions of other people's constructions, of what they and their compatriots are up to" (9). Therefore, the inputs of Vannini, Aniago, Black, and Walsham relate the interpretive analysts' focus on hermeneutic and phenomenological approaches of explaining realities through a given localespecific point of view or community's perspectives which highlight the nuance of locale-specific attributions. Hence, we adduce that individuals are regarded as belonging to the same locale specific worldview when in their interpretation they are instinctively guided by the same ideologies, thus their interpretations are propelled mostly by imbibed inclinations and attributions.

This is to say that, the variables which guide and propel an interpretive point of view and outcome of an individual within a locale-specific worldview are culturespecific ideologies, philosophies, faith, intentions, fears, inclinations, and interests. Elucidating further in this regard, we can deduce that core values and locale-specific worldviews define that community in many ways. Therefore, studying those values will help largely towards dependable analysis of meanings subsumed in them. The view of this paper is that the ideas that define an interpretive community are products of social construction of reality, which may be defined as a theory which explains how human realities primarily exist in different manifestations mainly because of social and interpersonal influences. Thus, theory of social construction of reality illuminates how "social order is the result of past human activity" and how "social order exists only and insofar as human activity continues to produce it" (Tänzler et al. 3). According to Wendy Leeds-Hurwitz, social construction of reality theory in line with the perspectives of the forerunners such as Peter Berger and Thomas Luckmann, Vivien Burr, James Carey, and Kenneth Gergen "addresses the processes by which people jointly construct their understandings of the world" (891). In another way, we can say that social contexts influence the shades and nuances of interpretation emanating from an interpretive community, who in line with Victoria Dickerson and Jeffrey Zimmerman on concept of social constructionist perspective, "locates meaning in an understanding of how ideas and attitudes are developed over time within a social and community context" (80). 


\section{VULTURES AND CANDLES AS METAPHORS IN A PARLIAMENT OF VULTURES AND THE CANDLES}

To foreground the social context of the interpretive community in discussing the projections of vulture metaphor in Nwabueze's A Parliament of Vultures, we will first look at relevant scholarly perspectives on various Nigerian denotation of vulture as despicable. Lazarus Baribiae Saale notes that "according to Ogoni tradition, individuals or groups whose life styles resemble vultures are nicknamed 'Dere' or 'Gbo Dere'” (107). He observes that this derogatory name is used to teach and articulate ethics in Ogoni culture. Furthermore, Saale notes that:

People are discouraged from behaving unethically in matters concerning the common good-group interest. Although, the beliefs and attitude of Ogoni people have changed in modern times, they still use the derogatory term, 'Dere', meaning vulture or 'Gbo Dere,' meaning group of vultures to describe unethical human behaviours. (107)

Similarly, James Tar Tsaaior in his essay "The Significance of Avian Metaphors in Akachi Adimora-Ezeigbo's Children of the Eagle" within the context of the novel attempts to juxtapose the qualities of the eagle and the vulture. In line with the projection in the text, Nigerians see the eagle as regal and elegant, whereas the vulture is "delineated as a wretched, emaciated, dull and physically unattractive bird principally because of its dietary habits" (172). Tsaaior notes that in line with the interpretive community propelled in Akachi Adimora-Ezeigbo's novel which reflects the Igbo as well as popular Nigerian worldview:

The hooded vulture (Necrosyrtes monachus) is seen around villages and towns, and because vultures survive on carrion, they are seen as metaphoric representations of human cannibals who 'feed' on human beings by exploiting, oppressing, repressing and dominating them unjustly. (172)

According to Uriel Okunrinmeta and Olugbenga O. Alabi in their exploration of the metaphors of corruption used in Wole Soyinka's Samarkand, Niyi Osundare's Waiting Laughters and Tayo Olafioye's The Parliament of Idiots, these writers similarly depict the vulture as metaphor acknowledged in Nigeria as attributes of despicable, destructive behaviours of individuals who are driven by greed and lack of patriotism to enrich themselves through corruption. They observe that "the vulture is another animal of prey whose attributes are used in the selected works to portray the corrupt practices of our political leaders" and "like the vulture, corrupt politicians and their cohorts are greedy, wasteful and callous" (37). In the words of Isa Abubakar Shehu, when an individual is called a vulture (angulu in Hausa language), it means that such a person is loathsome and untrustworthy (Shehu pers. comm.). This view is captured by Emmanuel Amase et al. in their analysis of 
Odia Ofeimun's poem "National Cakes," where they observe that Ofeimun uses the "vultures as a metaphor for unpatriotic leaders" in Nigeria, "who are incapable of performing patriotic acts, but only feed on what others have produced" therefore "this concept of vultures is a reflection on both economic and political attitudes of irresponsibility" (64).

In view of the above attributions, the playwright's application of the metaphoric noun vultures as a symbolic representation for the parliamentarians is noteworthy as well as critical. It is important that readers of Nwabueze's A Parliament of Vultures as well as its audiences during its enactment understand the metaphoric connotations of vulture by some ethnic groups in Nigeria as a means of understanding the contextualization of the interpretive communities. Though vulture is a name for a big, bald-headed scavenging and predatory bird whose species are found in most parts of the world, in Nigeria, it possesses local specific habit attributions as projected in the play A Parliament of Vultures. In Nigeria's major ethnic groups such as Igbo, Yoruba, Hausa, Ijaw, and Edo, a vulture is perceived as repulsive, hideous, despicable, and disgusting, just as applied by Nwabueze in A Parliament of Vultures.

According to Uwem Affiah, when an individual is described as a vulture, in line with the socio-cultural realities subsumed in A Parliament of Vultures, it suggests that the individual is ravenous, greedy, voracious, and insatiable, hence the legislators in the play are "thus likened to vultures and seen as possessing all these attributes" because metaphorically, "they prey on the people, scavenging them to death" (378). Similarly, Uriel Okunrinmeta and Olugbenga Alabi, observe that metaphoric attribution of animals such as vultures, locusts, and leeches in some Nigerian ethnic groups "reveals that their referents are destructive since they share with them such attributes as greed, selfishness, callousness, wastefulness, brutality, recklessness, pretentiousness and moral rottenness, among others, which have wreaked havoc on Nigeria as a nation" (30). In view of these, in some Nigerian cultures such as Igbo, Yoruba, Hausa and Edo, vultures are neither reared as pets nor hunted as food, because they are perceived as most revolting (Aniago 73). In context of the Igbo as the interpretive community, "the vulture represents all that is repulsive in nature-a scavenger that promptly arrives at the scene of all accidents" (Okafor 98). Furthermore, Okafor observes that the Igbo see vultures as a repulsive bird that would eat anything, hence the rhetoric "Onye si na ife oma adiro ya nma, nwunye ya mualu ya udene ka okulu, which means, he who does not like good things, may his wife give birth to a vulture for him to cuddle as his baby" (142). Consequently, Nwabueze's metaphoric description of some of the parliamentarians as vultures is telling and dense. Among other themes, the text through its representation of the prevailing realities of party politics in Nigeria, projects the theme of leadership failure. In his view on the context of leadership 
failure as a major theme in the play, Ngozi Anyachonkeya argues that $A$ Parliament of Vultures is a satire that "dramatically unveils the regrettable gamut of corruption and hypocrisy that polarize the political atmosphere in postcolonial Africa" (125). In line with Anyachonkeya's remark, Norbert Oyibo Eze notes that Nwabueze encapsulates the perennial "national question of poor leadership in Nigeria" (2). Furthermore, Eze observes that the play mirrors the "vulgar realities, indiscipline and unflattering characters that infest" Nigeria's polity (99). Similarly, Chukwuka Nwachukwu states that in the text, Nwabueze satirizes the "poverty of thought and predilection to criminal antics designed solely to satisfy the self with the common core" (389). Nwachukwu further contends that the playwright is understandably "miffed at the danger posed by this kind of practice coming as it does from those to whom the destiny of the nation is entrusted for safe-keeping" (389).

In portraying Madam Omeaku as a "vulture," the playwright characterizes her as a classic epitome of mediocrity, greed, and insensitivity, which has continued to spread through Nigeria's polity. Ironically, the play represents an answer to the demands captured in Nwaozuzu's The Candles for an end to military dictatorship in Nigeria; however the vulture metaphor indicates as well as portrays the masses irritation towards the ruling class who appear totally self-seeking and derailed in many ways just as the military. Thus, in line with the subsisting political and socioeconomic realities in Nigeria as represented in the return to civilian democratic rule in A Parliament of Vultures, one can deduce that democracy has not after all salvaged Nigeria, even though Nigerians widely believe that democracy remains a better option than a military regime. It is based on the social context of the interpretive community linked to A Parliament of Vultures that Affiah describes it as "a hilarious political satire" that portrays some inadequacies in party politics in Nigeria which gives room for emergence of some "total misfits who though lacking in intellectual vigour and moral decency, find themselves in parliament" and the executive arm "as a result of a poor political culture" (378). Indeed, the play epitomizes the consequences of gutter politics in Nigeria's democracy in recent years, which propels regression, ethnic tension, social unrest, and rebellions. It lucidly depicts insensitivity and greed as major retrogressive behaviours of these politicians. Through the utterance of the character Habamero, the Speaker of Parliament, the playwright projects the subsisting culture of reckless misappropriation of public funds.

HABAMERO. By the powers vested on me as the speaker of the House, and Chairman of this assembly, I approve the sum of two million naira for each member as inconvenience allowance. (Vultures 27)

HABAMERO. That's all right, madam. Perhaps the Very Reverend Jossy does not understand the role of Miss Omeaku in the House. Perhaps he does not understand 
that Madam used her pretty daughter to bring down the former Speaker of this House. And Madam has more jobs for her. (28)

HABAMERO. Take these papers. Give it to the director of the establishment whose name is on it. He will give you a brand new Honda accord for your use. Approved?

ALL. Approved!

MADAM OMEAKU. That's right. We can now toast.

[As they are about to toast, there is a wild knock at the door. Enter Mr. Omeaku]

OMEAKU. So this is what you people are doing? This is my nation's parliament at work. Do you know what you people are? You are vultures! This is a parliament of vultures. Eating my nation to death, leaving nothing for the masses to quench their thirst. (31)

Analyzing Habamero's behaviour and Mr. Omeaku's disgust, we can acknowledge that insensitivity to due process and apparent lack of ethical consciousness are primarily the factors that emboldened Habamero to make the frivolous fund approval. Thus Mr. Omeaku referred to Habamero and the members of parliament as vultures because their actions are deplorable, selfish, and repulsive. In condemnation of these acts, the character Dr. Parkers advises:

DR. PARKERS. [...] such colossal waste of public funds is unnecessary. I don't see any reason for it. The value of our currency is very low, the masses are suffering, civil servants in some states have not been paid their salaries for upwards of six months. I move that it be completely erased from the program. (64)

Notwithstanding the opposition of such action as characterized by Dr. Parkers, their obnoxious plans sailed through with the power of majority as being witnessed in the political space in real life. The "vultures in parliament" steal and launder the illicit funds into their overseas accounts. To indicate how this bad conduct has become a widely acknowledged practice by some Nigerian politicians, The US Department of State's Bureau for International Narcotics and Law Enforcement Affairs' 2015 report indicates that "money laundering in Nigeria takes many forms, including investment in real estate, wire transfers to offshore banks, political party and campaign financing; deposits into foreign bank accounts" (332). To illuminate further on the selfish and retrogressive realities of party politics in a traumatized economy, such as those enacted in the play, Madam Omeaku's response to Mr. Brown's question pertaining to why their party fielded Dr. Parkers as candidate in the election indicates how the "vultures in parliament" dubiously plan to perpetuate themselves in parliament to continue their crime against society. 
MADAM OMEAKU. Having lived in the United States of America for more than fifteen years we felt that he should have enough connections to help us put money in foreign banks.

MR. BROWN. He could have crashed like a park of cards if I hadn't stepped in to rescue him. Fortunately, the Returning Officer was my classmate. It wasn't difficult for me to negotiate the right figures for him as I did in your case. (10)

Mr. Brown's response to Madam Omeaku's supposition depicts the climate of fraud, manipulations and irregularities that have become associated with elections in Nigeria over the years. As regards this, Samuel Ehirim notes that "electoral frauds have been one of the major challenges to the growth and development of the country and these have grown steadily worse and more daring" (52). The play projects the subsisting practice, whereby the political party in government see political appointments as means of reward for their members who in one way or the other may have contributed to their success at the polls without considering their suitability for the positions. This is an action that negates meritocracy. Depicting this, the character Habamero states:

HABAMERO. I'm pleased to inform you in this august assembly that the other positions are not open for discussion in parliament. The party caucus has decided to ask party financiers to suggest a name or two each as the compensation for their indefatigable efforts in the promotion of the party. (78)

This is done with impunity regardless of glaring inefficiency of such appointees. For instance, Madam Omeaku, an illiterate hotelier turned politician was made the secretary of parliament because of her political affiliation with the Speaker of the House, Mr. Habamero, even though she lacks requisite experience. Her unsuitability for the task is exposed by her inability to properly write and read minutes of the House proceedings to the bewilderment of Parliamentarians. The Speaker unabashedly shields her despite glaring incompetence. The framing and unlawful arrest of the opposing members of parliament, Dr. Parkers and Mr. Otobo, who refused to join the corrupt majority, depict the prevailing use of blackmail and state forces to muzzle the opposition.

In The Candles, Nwaozuzu portrays the dysfunctional state of affairs in Nigeria and a disturbing level of fraudulent business conduct and government's inability to control and eradicate the ugly situation. The choice of the play's title relates to its story, which hovers around the light/illumination and darkness/regression metaphors. Also the metaphor of the composition of the gathered fortune-tellers relates to the representation of Nigeria's heterogeneous reality. The gathering of 
the fortune-tellers is aimed at rescuing a country which has been tottering and dawdling from one crisis to another.

KOKO. My Lords, chief Priests, Spiritualists, Thinkers and Potentates, this is the place, our rendezvous. The Security operatives painstakingly chose this house because of its seclusion ... very remote part of the Federal Capital Territory. In fact, the city is about a hundred miles from this place. (Candles 7).

KOKO. Only the President, the Service Chiefs, the Secretary to the Federal Military Government and my humble self the Minister for Information are aware of your mission tonight. (7)

Mr. Koko's introduction displays the working preference of the military government, who chooses to rely on mystics for solutions to governance challenges. It also displays the consistent state of emergency in which the military had to operate under because of the consistent question about their legitimacy to govern. Thus, this projects the military's preference for secrecy and their hatred for openness, accountability, and public scrutiny. As the meeting barely gets underway, the room abruptly goes dark. This is because the national grid is carrying out a routine power outage and the attempts to get the standby generator to start fails.

KOKO. Light Ah! The electricity is off. (He howls) Light, light ... ah! Why this outage ...

(Gathers himself) Em ... sorry gentlemen... Great mother, let me dash down quickly to the generator house and see what the matter is ... Torch light, torch light please ... (Tibet and Legion produce two torches... he grabs Tibet's, and makes a frantic exit) (8)

KOKO. Darkness. The technicians at the 'plant house' say that the standby generator cannot work. (8)

KOKO. Was supplied with adulterated fuel! (8)

Through the first comment by Mr. Koko, the playwright portrays unambiguously the painful condition of inadequate power supply that has been a major roadblock to economic development in the country. The second comment by Mr. Koko captures the consistent and disturbing state of unpreparedness of several publicly owned and managed utility establishments in the country. Moreover, the frantic efforts to remedy the nuisance occasioned by the sudden power outage projects the counterproductive penchant for "fire brigade approaches" to issues by the military regime. The generator was placed as a backup which will ensure elimination of manageable disruptions, but proper supervisory protocols are usually lacking or deficient, hence many government establishments are not properly serviced and maintained to ensure optimal operation. The failure of the generating set to start 
even though it is purported to be brand new, subsumes the nuance of incompetence, woeful state of abysmal maintenance culture, and lack of proper chain of supervisory framework, which exacerbate economic corruption. We also deduce from the Minister of Information's suggestion that the problem of the generator is that the technicians were supplied with adulterated fuel as a proclamation of poor standards and quality assurance regime, as well as the overwhelming incompetence that characterizes the military government.

The reference to adulterated petrol showcases the culture of impunity and corruption in the petroleum industry downstream sector in Nigeria, whereby adulterated fuel finds its way through the distribution channels to the consumers, despite extant laws that are in place to checkmate underhand practices. The cases of kerosene explosions and consequent causalities are attributable to adulteration, yet the ugly trend blossoms. In line with the findings of some scholars, adulteration of fuel is very rampant in Nigeria because the products of comparable quantities have different prices. The fuel dealers engage in adulteration to maximize profit, neglecting the damage it does to motor vehicles and the maiming and destruction of human lives that usually trails it. Kerosene becomes highly inflammable when it is mixed with fuel, and many unsuspecting families have experienced untold damages buying it.

In response to the problem brought about by the power outage, the following suggestions and plans were put forward by Koko and his guests:

KOKO. The city is about a hundred miles away. Going there is out of the question. It will take almost three hours for whoever goes to return, and time is definitely not on our side.

LAMA. ... Candles.

KOKO. Pardon?

LAMA. Candles that is what we need now.

KOKO. Yes, I think I agree with you Lord Lama. This is a good idea. I shall dash down to the nearby village to buy some candles, and who knows, the light might come back very soon (He exits) (9)

The remedy to the problem of ineffectual power supply by the National Power Grid system, the lack of maintenance and supervisory framework depicted through the failure of the "new" generating set, and the collusion of fuel marketers and relevant government agencies, is the resort to using candles, which is a metaphor 
for regression. The mindset and the recourse to this highly unreliable source of power supply as the available means of providing illumination typifies the context of regression in which the enacted Nigerian era has continued to swim in. Again beyond the physical context and metaphor of the candle as a means of creating illumination, the power outage which brings darkness is a dense and thick metaphor subsuming the fundamental encumbrance that the pursuance of enlightenment (illumination) has suffered under the military regimes. We learn from properly documented reports of the massive "brain drain" that characterized the period of military regime because of the disturbing state of "darkness" that negates "illumination" - a metaphor for socioeconomic advancement, creativity, and invention. The university system has not been able to come out of the terrible effects of the exodus of its best brains to other more viable countries during the period under examination. Brain drain led to the employment of mediocre scholars whose entrance in the system has continued to lower the standard of the citadel of learning.

Lastly, Nwaozuzu also brings to fore the predominance of Nigerian people's belief in the consistence of supernatural influence in people's day-to-day activities, situations, and circumstances. Here, the playwright ridicules the crop of leaders who place faith in numinous miracles more than empirical science and technology in solving crucial social issues.

\section{CONCLUSION}

The study examines the perennial question of poor leadership in Nigeria as articulated in Emeka Nwabueze's A Parliament of Vultures and Uche Nwaozuzu's The Candles. This paper points out that both playwrights, through the application of metaphors, did communicate that both plays establish how retrogressive political activities are largely the reason Nigeria's economic growth and social welfare have remained a dream. The thesis and core purview of this paper revolves around the metaphor and interpretive community's perspective of what can be referred to as "good" in politics, which subsumes the primal propelling interest of man to engage in politics. The pertinent nuance is that the notion of "good" is neither universal nor perpetually constant. What the collective interest in politics attempts to achieve is to come up with the widely accepted "good," and through subsisting laws that bind the people, continually uphold the same until people feel the need to review accordingly. Thus, a widely accepted "good" in politics in many climes include accountability, due process, and rule of law, which are in many ways the strongest tenets of democracy, hence the apparent popularity of democracy as the progressive model in many African nations including Nigeria. However, in $A$ 
Parliament of Vultures the instances of financial recklessness, lack of accountability, and lack of effectual democratic frameworks that will institutionalize due process, human rights, and rule of law are highlighted as the major encumbrances to the inclusive socioeconomic growth and wellbeing of Nigeria. Therefore, there is an urgent need to put in place measures that will check as well as bring these activities to a halt, in order to facilitate a major renaissance in Nigeria that will propel her to lofty heights as envisaged by the founding fathers. These measures include tightening of economic and financial crimes laws, alongside granting fullfledged independence to the agencies in charge of the monitoring and prosecution of perpetrators of financial crime through their political positions, and hastening prosecution with commiserate jail terms and political life ban on such individuals. Secondly, the electoral body in Nigeria should by an act of parliament be made fully independent of the government in power, directly funded by the Central Bank of Nigeria as appropriated by the National Assembly to enable it to perform its functions free of any form of interference by political gladiators. Electoral offenders should be brought to book to dissuade others from toeing such line, and a bill should be initiated as regard to appointment into political offices at all levels so that, when it is passed into law, appointment into political offices would be based on an individual's proven track record in a given field, qualification, and experience. It has also become critical that the parliamentary act on requirements for election into political office be re-evaluated and overtly amended to forestall the invasion of Nigeria's political space by misfits in the likes of the character of Madam Omeaku. If all these suggestions can be adopted and implemented in the nearest future, sanity will return to the polity, and Nigeria becoming the envy of many countrieswith citizens who will have every reason to be identified with the country-would be inevitable. The populist view is that because democracy apparently promises power to the masses more than any other governance framework that Nigeria and Africa have witnessed, Nigerians and Africans appear to show unwillingness to relive any form of dictatorship and authoritarianism. Although in Nwaozuzu's play the candles eventually came in handy as the only solution to the disappointment in not having more sophisticated lighting, their use of candles in the play's situation does not elevate to the status of the ideal, rather there is an interpretation and implication of deprivation and lack of expected standard of life. A candle is an unreliable and unstable power source; a little breeze flickers its light out. Any nation earnestly desirous of supplying its citizens light in the modern period must embrace progressive science, research, and development by investing significantly in functional education. 


\section{WORKS CITED}

Achebe, Chinua. The Trouble with Nigeria. Fourth Dimension Pub., 1983.

Adeagbo, A. Adekola and O. Olumide Omodunbi. "Election Gifting and the Ordeal of Democracy in Nigeria." European Scientific Journal, vol. 15, no. 5, 2019, pp. 119-131.

Adejumo, Kabir. “2019: Analysing Nigeria's Democracy 20 Years After." Sahara Reporter, 25 Jan. 2019, http://saharareporters.com/2019/01/25/2019-analysing-nigerias-democracy20-years-after\%E2\%80\%8B-adejumo-kabir\% $\% 2 \% 80 \% 8 \mathrm{~B}$.

Affiah, Uwem. "Vultures in Parliament: Perspectives of Emeka Nwabueze." American Journal of Social Issues and Humanities, vol. 2, no. 6, 2012, pp. 375-383.

Amase, Emmanuel, Aondover Kaan, and Christopher Nwabudike. "African Literature and English Language: A Political Literary Discourse." International Journal of Humanities and Social Science Invention, vol. 2, no. 3, 2013, pp.63-68.

Aniago, Emeka. "Polemics of Nigeria's Socio-Political Realities and Chinua Achebe's The Trouble with Nigeria." Rupkatha Journal on Interdisciplinary Studies in Humanities, vol. 9, no. 4, 2017, pp. 25-36.

--. "Political Culture as Product of Social Constructs in Emeka Nwabueze's A Parliament of Vultures." Ikenja: International Journal of Institute of African Studies, vol. 17, no. 1, 2017, pp. 68-76.

Anyachonkeya, Ngozi. "A Study of the Linguistic Repertoire of Emeka Nwabueze's A Parliament of Vultures." Theatre and New Horizons: Selected Essays on Emeka Nwabueze, edited by Uche-Chinemere Nwaozuzu, ABIC Books, 2011, pp. 125-140.

Arowolo, Dare, and Tolu Lawal. "Political Violence and Democratization in Nigeria (20032007)." Journal of Contemporary Politics, vol. 2, no.1, 2009, pp. 172-181.

Berger, Peter, and Thomas Luckmann. The Social Construction of Reality: A Treatise in the Sociology of Knowledge. Doubleday, 1967.

Black, Iain. "The Presentation of Interpretivist Research." Qualitative Market Research: An International Journal, vol. 9, no. 4, 2006, pp. 319-324.

Bratton, Michael, and Richard Houessou. "Demand for Democracy is Rising in Africa, But Most Political Leaders Fail to Deliver." Policy Paper, no. 11, 23 Apr. 2014, pp. 1-34. http://afrobarometer.org/sites/default/files/publications/Policy\%2opaper/ ab_r5_policypaperno11.pdf.

Burr, Vivien. An Introduction to Social Constructionism. Routledge, 1995.

Carey, James. Communication as Culture: Essays on Media and Society. Routledge, 1989.

Cheeseman, Nick. "Why Democracy and Authoritarianism Are Both on the Rise in Africa." Democracy in Africa, 19 Feb. 2019, http://democracyinafrica.org/ democracy-authoritarianism-rise/.

Chilton, Paul, and Christina Schaffner. "Introduction: Themes and Principles in the Analysis of Political Discourse." Politics as Text and Talk: Analytic Approaches to Political Discourse, edited by Paul Chilton and Christina Schaffner, John Benjamins Pub. Company, 2002, p. 5. 
Dickerson, Victoria, and Jeffrey Zimmerman. "Myths, Misconceptions, and a Word or Two about Politics." Journal of Systemic Therapies, vol. 15, no. 1, 1996, pp. 79-88.

Eze, Norbert Oyibo, "Political Jobbers and the Leadership Question in Emeka Nwabueze's A Parliament of Vultures." Theatre and New Horizons, edited by Uche-Chinemere Nwaozuzu, pp. 94-108.

Fish, Stanley. "Rhetoric, Phenomenology, and Reader Response." Literary Theory: An Anthology, edited by Julie Rivkin and Michael Ryan, Blackwell Pub., 2004, pp. 217-221.

Geertz, Clifford. The Interpretation of Cultures. Basic Books, 1973.

Gergen, Kenneth. An Invitation to Social Construction, SAGE Pub., 1999.

--. "The Social Constructionist Movement in Modern Psychology." American Psychologist, vol. 4, no. 3, 1985, pp. 266-275.

Gergen, Mary, and Kenneth Gergen, editors. Social Construction: A Reader. SAGE Pub., 2003.

Iheonu, Chimere O., and Nathaniel E. Urama. "Addressing Poverty Challenges in Nigeria." AfriHeritage Policy Brief, no. 21, July 2019, pp. 1-5.

Leeds-Hurwitz, Wendy. "Social Construction of Reality." Encyclopedia of Communication Theory, edited by Stephen W. Littlejohn and Karen A. Foss, SAGE Pub., 20oo, pp. 891-894.

McLean, Iain, and Alistair McMillan. Oxford Concise Dictionary of Politics, 3rd ed. Oxford UP, 2009, pp. 422-423.

Nwabueze, Emeka. A Parliament of Vultures. ABIC Books, 2011.

Nwachukwu, Chukwuka. "The Blind, the Deaf and the Music: An Inter-textual Concourse in Emeka Nwabueze's A Parliament of Vultures and Esiaba Irobi's Cemetery Road". The International Journal of Humanities and Social Studies, vol. 3, no. 8, 2015, pp. 387-393.

Nwaozuzu, Uche-Chinemere. The Candles. St. Francis Pub., 2010.

Ofeimun, Odia. "National Cakes." The Poet Lied and Other Poems, Longman, 198o, p. 14.

Ojaide, Tanure. The Fate of Vultures and Other Poems. Malthouse P, 1990.

Ojakorotu, Victor, and Fidelis Allen. "From Authoritative to Democracy in Nigeria: Citizens' Welfare a Myth or Reality." Journal of Alternative Perspective in the Social Sciences, vol. 1, no. 2, 2009, pp. 152-192.

Okafor, Mary-Blossom Chinyelum. Theatre of Life: Rituals, Transition and Progression among the Igbo. 1998. U of Plymouth, PhD dissertation.

Okolo, Chukwudum Barnabas. Squandermania Mentality: Reflections on Nigerian Culture. U Trust Pub., 1994.

Okunrinmeta, Uriel, and Olugbenga Alabi. "Cultural-Conceptual Analysis of Some Metaphors of Corruption in Nigerian Literature." Asian Journal of Social Sciences and Humanities, vol. 3, no. 3, 2014, pp. 30-43.

Olafioye, Tayo. The Parliament of Idiots. Kraft Books, 2002.

Osundare, Niyi. Waiting Laughters. Malthouse P, 1990.

Saale, Lazarus Baribiae. "Vulture Significance in Ogoni Culture." International Journal of

Language, Literature and Gender Studies (LALIGENS), vol. 6, no. 14, 2017, pp. 104-110.

Schwandt, Thomas. Dictionary of Qualitative Inquiry, 2nd ed., SAGE Pub, 2001. 
Shehu, Isa Abubakar. "Vulture in Hausa in Culture." Personal communication, 24 Mar. 2020.

Soyinka, Wole. Samarkand and other Markets I Have Known. Crucible, 2002.

Tänzler, Dirk, Konstadinos Maras, and Angelos Giannakopoulos. "The Social Construction of Corruption: Theoretical Reflections." The Social Construction of Corruption in Europe, edited by Dirk Tänzler, Konstadinos Maras, and Angelos Giannakopoulos, Ashgate Pub., 2012, pp. 13-29.

Tsaaior, James Tar. “The Significance of Avian Metaphors in Akachi Adimora-Ezeibgo's Children of the Eagle." Kunapipi, vol. 29, no. 2, 2014, pp. 167-175.

United States Department of State Bureau for International Narcotics and Law Enforcement Affairs. Money laundering and financial crimes country database, 2015. https://2009-2017.state.gov/documents/organization/239329.pdf.

Vannini, April. "Interpretive Theory." Encyclopedia of Communication Theory, edited by Stephen W. Littlejohn and Karen A. Foss, pp. 557-562.

Walsham, Geoff. "Doing Interpretive Research." European Journal of Information Systems, vol. 15, 2006, pp. 320-330.

World Data Lab. The Percentage of Nigerians Living in Extreme Poverty Could Increase by 203o. World Poverty Clock, 2019. https://worldpoverty.io. 